\title{
Intrauterine Infusion of Lugol's Iodine Improves the Reproductive Traits of Postpartum Infected Dairy Cows
}

\author{
Faisal Omer Ahmed ${ }^{1}$, Adil Salim Elsheikh ${ }^{1,2}$ \\ ${ }^{I}$ Department of Reproduction and obstetrics, Faculty of Veterinary Medicine, University of Khartoum, Shambat, \\ Sudan \\ ${ }^{2}$ Department of Applied Medical Sciences, Community college, Najran University, Saudi Arabia
}

\begin{abstract}
This study was conducted to investigate the effects of infusion of $1 \%$ Lugol's iodine into infected uteri of postpartum (PP) dairy cows on uterine involution (UI), appearance of the first dominant follicle (DF), recrudescence of the first oestrus (FO), days open (DO), rate of service per conception and calving interval $(C I)$. Forty dairy cows that were diagnosed with severe uterine bacterial infection during early PP were divided randomly into two equal groups: $A(n=20$ cows) and $B(n=20$ cows $)$. Group $A$ was intra-uterine infused with $1 \%$ Lugol's iodine on day 5 PP. Group B was left untreated, to serve as a control. The result showed that infusion of $1 \%$ Lugol's iodine significantly $(P<0.001)$ reduced, the time to complete UI by 16 days, appearance of the first DF by 2.7 days, resumption of FO by 91 days, DO by 160 day, rate of service by 3.4 and CI by 151 days, compared to the untreated control group. It is concluded that intra-uterine infusion of $1 \%$ Lugol's iodine improves the reproductive traits of cows with severe uterine bacterial infection.
\end{abstract}

Key words: Lugol's iodine, postpartum, reproductive traits, cow

\section{Introduction}

Presence of pathogenic bacteria in the uteri of dairy cows during early PP causes endometritis, decreases reproductive efficiency and perturbs embryo survival $[1,2,3,4,5]$. During early PP infection of the uteri of cows with bacteria induces inflammation and reduce the secretion of the gonadotropin hormones (FSH and LH) necessary for follicular growth, consequently perturbs or even impairs ovulation in dairy cattle [6]. This PP uterine bacterial infection is associated with decreased reproductive efficiency in dairy cows $[5,7,8]$. It has been reported that $90 \%$ of PP bovine uteri are infected with bacteria [9]. The PP period in the Sudan is unnecessarily long in cross-bred dairy cows due to uterine bacterial infection $[5,10]$. Ninety three percent of the dairy cows in the Sudan were diagnosed with uterine bacterial infection during early PP [5]. This bacterial infection occurs as a result of poor sanitation around parturition, retention of the foetal membranes, dystocia, and descending bacterial infection. The routine intra-uterine infusion of diluted Lugol's iodine (1\%) for management of PP in dairy cows is not a common practice in the Sudan. Diluted Lugol's iodine is the cheapest and the recommended method for uterine bacterial infection compared to hormonal treatment [11]. Lugol's iodine is a transparent brown liquid of $10 \%$ potassium iodide $(\mathrm{KI}), 5 \%$ iodine and $85 \%$ distilled water. It has broad spectrum bactericidal effects, rapid on- set and short half life. It was first developed by the French physician, Jean Lugol in 1829 [12]. The mode of action of Lugol's iodine on reproductive system is fully understood, where it causes hyperaemia of the uterine mucosa and enhances uterine blood circulation, which consequently leads to high degree of iodine absorption [13]. The absorbed iodine stimulates production of thyroxine under control of pituitary and hypothalamus glands, which increases body's metabolism including the reproductive tract [13]. Diluted Lugol's iodine is an efficient protocol that improves the PP reproductive performance in the dairy cows $[13,14]$. Its infusion into the uteri of cows suffering from severe uterine bacterial infection improved their reproductive efficiency $[15,16]$ and it is an effective regimen for treatment of inactive ovaries in dairy cows [11]. In view of the above mentioned facts, the main objective of this study was to determine the effects of intra-uterine infusion of diluted Lugol's iodine (1\%) on day $5 \mathrm{PP}$ on UI, appearance of the first DF, recrudescence of the FO, DO, rate of service per conception and $\mathrm{CI}$ in postpartum dairy cows with uterine bacterial infection.

\section{Materials And Methods}

Study area: This study was carried out at Khartoum University Dairy Farm about 4 Km North to the Faculty of Veterinary Medicine at Shambat, North Khartoum.

Animals: The study was conducted on 40 cross-bred (Friesian $\times$ Kenana) dairy cow 4 to 7 years old. Their body condition score (BCS) was between 2.5 to 3.5 according to the five-scale point system outlined elsewhere [17]. 


\section{Diagnosis of uterine bacterial infection}

These cows were diagnosed as having severe uterine bacterial infection as described elsewhere $[5,18]$. Transcervical guarded sterile disposable swabs were collected from the endometrium of each cow on day 5 PP $[5,19,20)$. The swabs were transferred to sterile test tube and were cultured aerobically within 2 hours on a preequilibrated sheep blood agar for 2 hours, and then on MacConkey agar and incubated at $37^{\circ} \mathrm{C}$ over-night. Identification of bacteria was based on the characteristics of the colony, gram-stain and morphology [18]. Bacterial growth on the plates was scored semi -quantitatively depending on the number of bacterial colonies $[5,19]$. The cow was considered severely infected when the numbers of the bacterial colonies on the plate were more than 100 .

Uterine involution (UI): It was determined by rectal palpation every other day after parturition till complete involution. The uterus was described to be involuted when the size of the uterine horn was equal to two fingers and the uterine body was palpated in the pelvic cavity $[5,21]$. The complete uterine involution was assumed when the animal showed the first PP heat [22].

Postpartum dominant follicles (DF) detection: The PP follicular waves were manually assessed per rectum at two days intervals until the first postpartum DF was detected [5, 23].

Heat detection and servicing: All the cows in the herd were checked for oestrus signs by visual observations by well trained herdsmen thrice a day: early in the morning at 7:00 am, in the mid day at 12:00 and at 7:00 pm for at least 30 minutes [22]. The cow was recorded on heat when it became restless, licked the perineum of other cows, jumped on other cows, allowed other cows or the bull to mount her, it bellowed and there was a transparent clear vaginal mucus discharge. The cow was considered in a full response when it stood to be mounted by the bull and mating was completed [21,22]. Cows in heat were serviced with bulls of known fertility.

Days open (DO): It was done by calculating the intervals in days from calving to the subsequent effective service date of those cows that conceived [21,22].

Calving intervals (CI): this parameter was counted as described elsewhere [21, 22, 24], where the CI is stated as the duration between two consecutive calvings.

Early PP intra-uterine infusion of 1\% Lugol's iodine: A volume of $150 \mathrm{ml}$ of $1 \%$ Lugol's iodine (10\% potassium iodide, $5 \%$ iodine and $85 \%$ distilled water) was infused on day 5 after parturition in the uteri of the dairy cows [25]. The apparatus used for PP uterine infusion consisted of a 2 liter stainless steel jug with a projected nozzle at the bottom. A rubber tube of $100 \mathrm{~cm}$ long connected with $30 \mathrm{~cm}$ catheter was fitted to the nozzle of the apparatus [26].

\section{Experimental Design}

A one factorial experiment was designed to execute the effects of intra-uterine infusion of diluted Lugol's iodine (1\%) on the PP reproductive performance of cross-bred dairy cows suffered bacterial uterine infection. Forty dairy cows suffered severe PP uterine infection were used. The cows were divided randomly into two groups. Group (A) and group (B) of 20 cows each. Group A was intra-uterine infused with $150 \mathrm{ml}$ diluted Lugol's iodine $(1 \%)$ on day 5 PP $[14,16]$. Group B was left as untreated control. The parameters in question were recorded as mention above.

\section{Statistical Analysis}

Data generated were subjected to analysis of variance (ANOVA) followed by Fisher's exact test using Stat View Analytical Computer Package Version 4.01. Significant differences at $\mathrm{P}<0.05$ were considered.

\section{Results}

Uterine involution (UI): Infusion of diluted Lugol's iodine on day 5 into the uteri of PP severely infected dairy cows significantly $(\mathrm{P}<0.001)$ accelerated UI compared to the control (Fig. 1). Infusion of diluted Lugol's iodine during early PP accelerated UI by about 16 days. The mean length of time taken for UI of infused cows was $17.20 \pm 0.40$ days. This value was lower than that of the untreated control (33.40 \pm 0.90 days). 


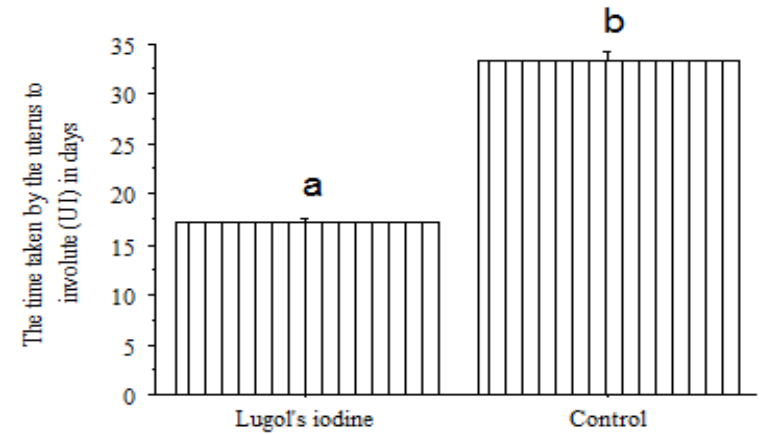

Fig. 1. Effects of intra-uterine infusion of Lugol's iodine on day $5 \mathrm{PP}$ on the time taken for uterine involution in dairy cows $\left({ }^{\mathrm{a}, \mathrm{b}} \mathrm{P}<0.001\right)$.

First dominant follicle (DF): Time taken for appearance of the DF in the cows that were infused with diluted Lugol's iodine on day $5 \mathrm{PP}$ was significantly reduced $(\mathrm{P}<0.001)$ (Fig. 2). The mean length of the time taken for the appearance of the first DF for these cows was $6.90 \pm 0.20$ days. This value was significantly shorter than that of the control (9.60 \pm 0.40 days $)$.

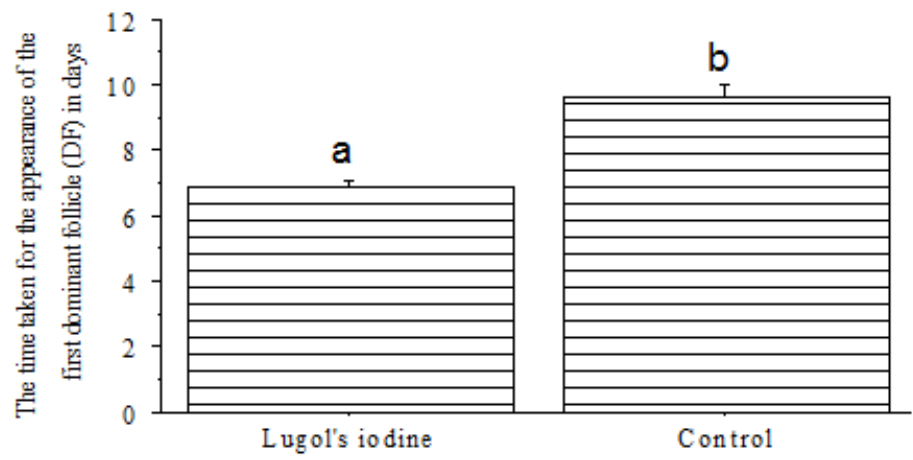

Fig. 2. Effects of intra-uterine infusion of Lugol's iodine on day $5 \mathrm{PP}$ on the appearance of first DF in dairy cows $\left({ }^{\mathrm{a}, \mathrm{b}} \mathrm{P}<0.001\right)$.

Resumption of the first oestrus (FO): The dairy cows that suffered severe uterine bacterial infection and infused with diluted Lugol's iodine on day 5 PP had a significantly $(\mathrm{P}<0.001)$ reduced time taken to the FO compared to the control (Fig. 3). The recrudescence of the FO was reduced by 91 days as compared to the control. The mean length of the time taken for resumption of the FO in treated cows was $42.70 \pm 1.90$ days. This value was significantly shorter than that of the untreated cows (133.90 \pm 4.40 days).

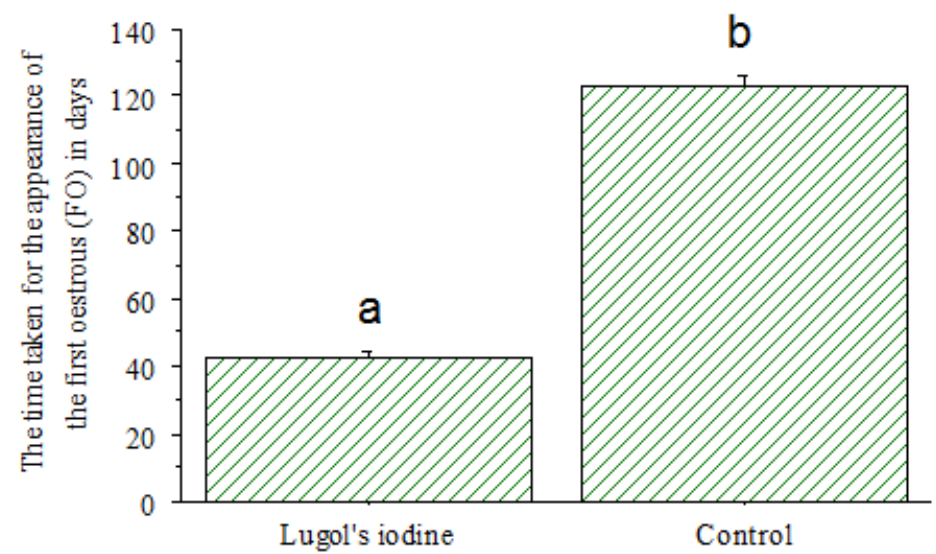

Fig. 3. Effects of intra-uterine infusion of Lugol's iodine on day 5 PP on the appearance of the FO in dairy cows $\left({ }^{\mathrm{a}, \mathrm{b}} \mathrm{P}<0.001\right)$.

Days open (DO): The DO of the treated cows was significantly $(\mathrm{P}<0.001)$ reduced compared to that of the control (Fig. 4). The mean length of the DO of the treated cows was $52.10 \pm 2.0$ days, while, that of the untreated control was $212.40 \pm 8.20$ days. 


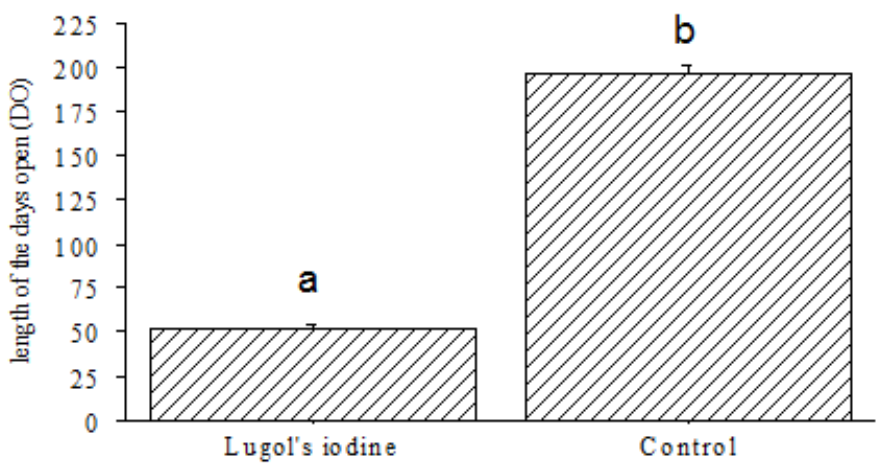

Fig. 4. Effects of intra-uterine infusion of Lugol`s iodine on day $5 \mathrm{PP}$ on the length of the DO in dairy $\operatorname{cow}\left({ }^{\mathrm{a}, \mathrm{b}} \mathrm{P}<0.001\right)$.

The rate of service per conception: The rate of service per conception was improved $(1.10 \pm 0.10)$ for the treated cows (Fig. 5). This value was significantly $(\mathrm{P}<0.001)$ lower than that of the untreated control $(4.50 \pm$ $0.20)$.

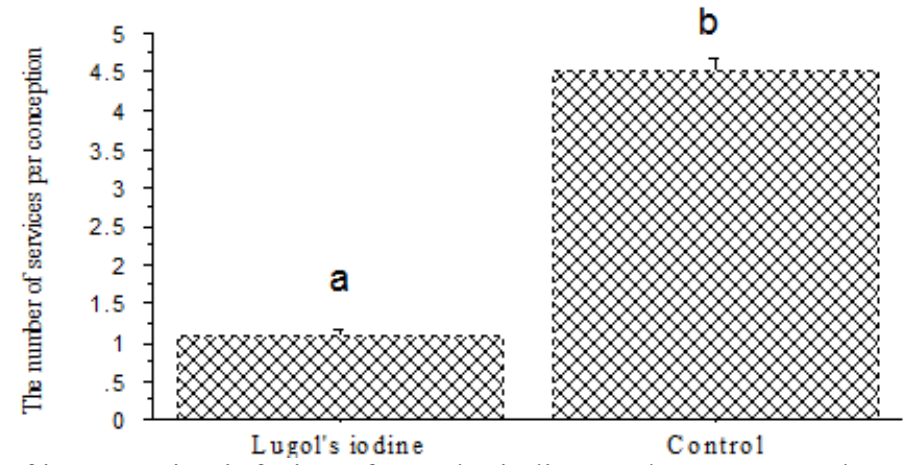

Fig. 5. Effects of intra-uterine infusion of Lugol's iodine on day 5 PP on the number of services per conception in dairy cows $\left({ }^{\mathrm{a}, \mathrm{b}} \mathrm{P}<0.001\right)$.

Calving interval (CI): The infusion of diluted Lugol's iodine on day 5 PP significantly $(\mathrm{P}<0.001)$ reduced the CI (Fig. 6). Infusion with diluted Lugol's iodine on day 5 PP shortened the CI by about 158 days. The mean length of the $\mathrm{CI}$ for the treated cows was $324.90 \pm 6.50$ days.

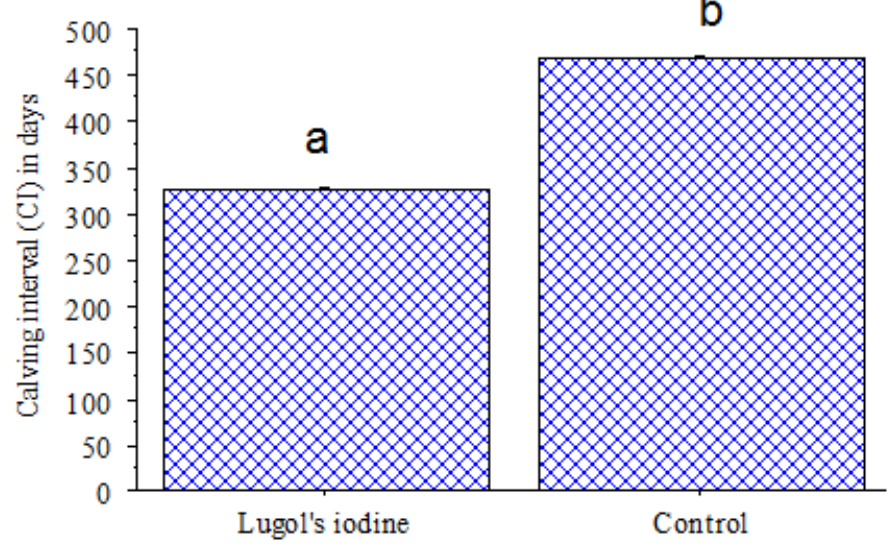

Fig.6. Effects of intra-uterine infusion of Lugol's iodine on day $5 \mathrm{PP}$ on the length of the CI in dairy cows $\left({ }^{\mathrm{a}, \mathrm{b}} \mathrm{P}<0.001\right)$.

\section{Discussion}

This study indicated that the problem of reduced PP reproductive efficiency could be solved by intrauterine infusion of diluted Lugol's iodine. The uteri of all cows used in this study had severe uterine bacterial infection. Thus; the infected untreated cows experienced a dramatic decrease in PP reproductive efficiency. Contrary those infused with 1\% Lugol's iodine during the first week PP had accelerated UI. Lugol's iodine is known to increase the endometrial hyperaemia, increase its blood supply and when the iodine in Lugol's 
solution is absorbed, it goes to the thyroid gland and associates with the binding globulin (TBG) therein to produce the thyroxin; under the control of the thyroxin releasing hormone (TRH) and the thyroxin stimulating hormone (TSH). The thyroxin is essential for internal cellular metabolism, improvement of follicular development, ovulation and maintenance of pregnancy [27]. Furthermore, Lugol's iodine has a bactericidal effect [3]. These activities of iodine enhance healing of the endometrium and restoration of its activities to produce $\mathrm{PGF}_{2 a}$, which is responsible for the acceleration of UI in dairy cows. The internal cellular metabolism of the reproductive system including the ovaries is also improved by infusion of diluted Lugol's iodine [28]. Thus, in this study the initiation of the first follicular wave, the appearance of the first DF and the recrudescence of the FO were accelerated. The DO and CI were reduced. Moreover, the rate of service per conception at subsequent breeding was improved. These results are in agreement with those of Knutti et al. [15] and Edwell et al. [16] who reported that intra-uterine infusion of diluted Lugol's iodine during early PP reduces the time taken for UI, resumption of the first follicular wave and appearance of the first DF, recrudescence of the FO, minimizes DO, $\mathrm{CI}$ and improves the rate of service per conception in cows with severe uterine bacterial infection. This increased conception rate is surely due to the improvement of the uterine environment, as a result of the potent bactericidal effect of the solution. When the uterine environment is improved the ovary becomes able to release high quality oocyte and the uterus is capable of producing more uterine milk which helps embryo implantation [29].

It is concluded that intra-uterine infusion of 1\% Lugol's iodine improves the reproductive traits of cows with severe uterine bacterial infection.

\section{References}

[1] I. M. Sheldon, D.E. Noakes, A. N. Rycroft, and H. E. Dobson. Influence of uterine bacterial contamination after parturition on ovarian dominant follicle selection and follicle growth and function in cattle, Reproduction (123), 2002,837 - 845.

[2] I. M. Sheldon, D.E. Noakes, A. N. Rycroft, and H. E. Dobson. The effect of intra-uterine administration of estradiol on postpartum uterine involution in cattle, Theriogenology (59), 2003, 1357 - 1371.

[3] I. M. Sheldon, G. S. Lewis, S. Le Blanc, and R.O. Gilbert R. O. Defining postpartum uterine disease in cattle, Theriogenology 65 (8), 2006, $1516-1530$.

[4] J. R. Foild, M. Kulscar, A. Pecsi, B. Hughe, and J. Lohuis, J. Bacterial complications of postpartum uterine involution in dairy cows, Reprod. Sci. 96(3-4), 2006, 265 - 281.

[5] F. O. Ahmed and A. S. Elsheikh. Uterine bacterial infection during postpartum delays the recrudescence of the reproductive traits in dairy cows, J Am Sci 2013,9 (6),593-598.

[6] G. N. Opsomer, Y. T. Grohn, and A. Kruif. (2000). Risk factors for postpartum ovarian dysfunction in high producing dairy cows in Belgium, Theriogenology, (53),2000, 841 - 857.

[7] P. M. Bartlett, H. Kirk, M. Wilk, and J. Kaneene. Mastitis complex in Michigllan Hulstien Friesian cattle incidence, descriptive, epidemiology and estimated economic impact, Prev. Vet. Med. (4), 1986, 235 - 240.

[8] G. F. Huszenicza, M. Fodor and M. Vomas (1999). Uterine bacteriology, resumption of cyclic ovarian activity and fertility in postpartum dairy cows kept in large-scale dairy herds. Reprod. Domest Anim., (34), 1999, 237 - 245.

[9] K. E. Leslie. The events of normal and ubnormal postpartum reproductive endocrinology and uterine involution in dairy cows, Can. Vet. J. 24 (3), 1983, $67-71$.

[10] F. O. Ahmed. (2008). The efficacy of intra-uterine infusion of iodine compound on the reproductive efficiency of postpartum and repeat breeder cross-bred dairy cows in the Sudan, doctoral diss, University of Khartoum Sudan, 2008.

[11] G. A. Megahed, M. Anwar and M. Salwa. (1995). Thyroid activity in Egyptian buffalo cows with ovarian inactivity and trials for treatment by intrauterine infusion of Lugol's solution, Proc. $3^{\text {rd }}$ Science Congress of The Egyptian Society for Cattle Diseases, Assuit-Egypt, 1995, $211-217$.

[12] A. D. Koujan, E. M. Hussein, M. Ayoub, and M. Afiefy. Therapeutic efficacy of Povidone iodine (Bectadine and Dichloroxylenol) (Septocid) in Holstein cows affected with endometritis and/or cervicitis, Acta. Vet. Hung. 44 (1), 1996, $111-119$.

[13] A. J. Sanchez. Iodine in bovine nutrition, J. Anim. Sc. (2), 1995, $95-120$.

[14] R. E. Mutiga. Treatment of the repeat breeder cow syndrome in Kenya. Trop. Anim. Prod. 10(4), 1978,223 - 228.

[15] B. J. Knutti, U. Kupfer, and A. Busato. Reproductive efficiency of cows with endometritis after treatment with intra-uterine infusion or prostaglandin injections or no treatment, J. Vet. Med. Series. A. 47(10), 2000, $609-612$.

[16] M. S. Edwell, K. Zduncz, and T. Janowski. (2004). Comparative study on the efficacy of hormonal and non-hormonal treatment method in ovarian function affected dairy cows, Bull Vet. Inst pula way (48), 2004, 265 - 267.

[17] G. M. Wildman, J. Kotwiga, W. Slanger and K. Johnson (1982). Effects of suckling on pituitary responsiveness to GnRH hormones throughout the early postpartum of beef cows. J. Anim. Sci. (54), 1982, $594-603$.

[18] G. I. Barrow, and R. K. Feltham, R. K. Manual for the identification of medical Bacteria. $3^{\text {rd }}$. (Cambridge University Press), 1993,50 -150 .

[19] D. E. Noakes, L. Wallace, and G. R. Smith (1999). Bacterial flora of the uterus of cows after calving on two hygienically contrasting farm, Vet. Rec. (128), 1999, $440-442$.

[20] I. M. Sheldon, A. N., Rycroft and C. Zhou. Association between postpartum pyrexia and uterine bacterial infection in dairy cows, Vet, Record 154(10), 2004, $289-293$.

[21] G. H. Arthur, D.E. Noakes, P. Harold, and T. J. Parkison Veterinary Reproduction and Obstetrics, 7th ed. (WB. Sunderland Co Ltd.), 1998.

[22] A. S. El Sheikh and Ahmed, F. O. The effect of administration of PGF2 $\alpha$ during postpartum on reproductive efficiency of cross bred dairy cows in the Sudan, J. Anim. Vet. Adv. 3 (8), 2004, 495 - 499.

[23] P. R. Duffy, M. A. Crowe, M. A., Boland and J. F.Roche, J. F. Effect of exogenous LH pulses on the fate of the first dominant follicle in postpartum beef cows nursing calves, J. Reprod. Fertil. 118(1), 2000, 9 - 17.

[24] D. R. Bath, F. Dickinson, and F. Appleman, R. Dairy cattle principles, practices, problems and profits. $3^{\text {rd }}$ ed. (Lea and Febiger Philadeiphia), 1985, $284-258$. 
[25] R. L. Geiser, H. Siegenthaler, and J. Martig. Effectiveness of local treatment using a PVP. Iodine compound for retained placenta in cows. Ber/munch tierarztl wochenschr. 108(7), 1995, 264 - 268.

[26] S. M. Elsanousi, and A. B. Eltayeb. . Bacteria isolated from uterine washings from mares in the Sudan. Equine Vet. J. 11(4), 1979 $219-222$.

[27] H. O. Yu, and M. H.Tak-yin, M. H. The efficiency of Povidone iodine pessaries in a start, low-dose treatment regime on candidal, trichomonal and nonspecific vaginitis. Posgrad. Med. J. 69 (sppl3), 1993, $58-61$.

[28] A. K. Sarkar (2006). Therapeutic management of anoestrus cows with diluted Lugol's iodine and massage on reproductive organs. Res. J. Anim. \& Vet. Sci.. 1(1), 2006, 30 - 32.

[29] G. E. Oakley. Survival and fertility of dairy cows following uterine prolapse. New Zealand Vet. J. 40(3), 1992, 120 - 122. 